\title{
Effect of different plant species in pilot constructed wetlands for wastewater reuse in agriculture
}

\author{
Salvatore Barbagallo, Giuseppe L. Cirelli, Alessia Marzo, Mirco Milani, Attilio Toscano \\ Department of Agri-food and Environmental Systems Management, University of Catania, Catania, \\ Italy
}

\begin{abstract}
In this paper the first results of an experiment carried out in Southern Italy (Sicily) on the evapotranspiration (ET) and removal in constructed wetlands with five plant species are presented. The pilot plant used for this study is made of twelve horizontal sub-surface flow constructed wetlands (each with a surface area of $4.5 \mathrm{~m}^{2}$ ) functioning in parallel, and it is used for tertiary treatment of part of the effluents from a conventional municipal wastewater treatment plant (trickling filter). Two beds are unplanted (control) while ten beds are planted with five different macrophyte species: Cyperus papyrus, Vetiveria zizanoides, Miscanthus x giganteus, Arundo donax and Phragmites australis (i.e., every specie is planted in two beds to have a replication). The influent flow rate is measured in continuous by an electronic flow meter. The effluent is evaluated by an automatic system that measure the discharged volume for each bed. Physical, chemical and microbiological analyses were carried out on wastewater samples collected at the inlet of CW plant and at the outlet of the twelve beds. An automatic weather station is installed close to the experimental plant, measuring air temperature, wind speed and direction, rainfall, global radiation, relative humidity. This allows to calculate the reference Evapotranspiration $\left(\mathrm{ET}_{0}\right)$ with the Penman-Monteith formula, while the ET of different plant species is measured through the water balance of the beds. The first results show no great differences in the mean removal performances of the different plant species for TSS, COD and E.coli, ranged from, respectively, $82 \%$ to $88 \%, 60 \%$ to $64 \%$ and 2.7 to 3.1 Ulog. The average removal efficiency of nutrient (64\% for TN; 61 for $\mathrm{NH}_{4}-\mathrm{N}, 31 \%$ for $\mathrm{PO}_{4}-\mathrm{P}$ ) in the P.australis beds was higher than that other beds. From April to November 2012 ET measured for plant
\end{abstract}

Correspondence: Alessia Marzo, Department of Agri-food and Environmental Systems Management, University of Catania, Via Santa Sofia 100, Catania 95123, Italy.

Tel. +39.095.7147.593 - Fax: +39.095.7147.600.

E-mail: alessia.marzo@unict.it

Key words: constructed wetlands, cyperus papyrus, vetiveria zizanoides, miscanthus $x$ giganteus, arundo donax, phragmites australis.

○Copyright S. Barbagallo et al., 2013

Licensee PAGEPress, Italy

Journal of Agricultural Engineering 2013; XLIV(s2):e160

doi:10.4081/jae.2013.s2.e160

This article is distributed under the terms of the Creative Commons Attribution Noncommercial License (by-nc 3.0) which permits any noncommercial use, distribution, and reproduction in any medium, provided the original author(s) and source are credited. species were completely different from $\mathrm{ET}_{0}$ and $\mathrm{ET}_{\text {control }}$, underlining the strong effect of vegetation. The cumulative evapotranspiration highest value was measured in the CWs vegetated with Paustralis (4,318 mm), followed by A.donax (2,706 mm), V.zizanoides $(1,904)$, M.giganteus $(1,804 \mathrm{~mm})$, C.papyrus $(1,421 \mathrm{~mm})$.

\section{Introduction}

Agriculture sector is the main user of water in the Mediterranean region. The increasing competition for good-quality water among different water-use sectors in the Mediterranean region has decreased freshwater allocation to agriculture. The general decreasing trend for water supply and the need for sustainable use of the available water resources make essential to find alternative water sources like urban treated wastewater (TWW) through reuse practice (Barbagallo et al., 2012). The use of treated wastewater for irrigation in agriculture combines two advantages. First, using the fertilizing properties of the water eliminates part of the demand for synthetic fertilizers and contributes to decrease the level of nutrients in rivers. Second, the practice increases the available agricultural water resources.

Although the reuse of wastewater is potentially beneficial, it raises concerns such as soil and crop contamination by pathogens and thus public health issues. As a consequence, the wastewater methods used to treat wastewater for agricultural irrigation, have to be able to produce a final effluent that ensures the safely use of wastewater without risk to human health, and that complies with national quality standards for reclaimed wastewater (Toscano et al., 2013).

The Department of Agri-food and Environmental Systems Management, of Catania University, conducts, since 1990, studies on the possibility to reuse wastewater for irrigation purposes with tertiary treatment performed by constructed wetlands (CWs). The adoption of CWs, widely applied for the treatment of different varieties of wastewater (Vymazal, 2009), combined with conventional treatment plants, seem to be an attractive solution for wastewater purification, able to improve water quality through efficient pollutant removal, with low cost and no environmental impact (Katsenovich et al., 2009).

An important issue to consider when constructed wetlands is used for wastewater treatment, is the hydrological regime. In subsurface flow wetlands, the key components of the hydrologic cycle, are rainfall and evapotranspiration (ET), the process by which water moves from wetlands into the atmosphere through plants and medium. In CWs these variables may influence pollutant removal efficiency since precipitation dilutes the pollutant concentration and increases throughflow (IWA, 2000), shortening the contact time between waterborne substances and the wetland ecosystem. By contrast, ET decreases wastewater volume reducing outflow and concentrating the pollutants, but it does increase retention time which allows longer interaction with the wetland ecosystem (Kadlec and Wallace, 2009).

In mild temperate climates annual rainfall slightly exceeds annual 
ET and there is little effect of atmospheric gains and losses over the course of a year. But most climatic regions have a dry season and a wet season, which vary depending upon geographical setting. As a consequence ET losses may have a seasonally variable impact (Kadlec and Wallace, 2009). Unfortunately, the specific effects of ET on constructed wetland performance have not been thoroughly investigated because good ET estimates are hard to obtain (USEPA, 2000), even if better evaluation of ET can improve CW design and produce better predictions of simulation models.

The main objectives of this study, were to compare the individual performances of five emergent plant species, planted in a pilot-scale horizontal subsurface flow (H-SSF) CW, in term of capability to comply with Italian limits (Italian regulation, 2003) and with WHO guidelines (2006) for wastewater reuse in agriculture. The evapotranspiration (ET) rates and crop coefficients of the tested plant species were also assessed. Materials and methods

\section{Site characteristics}

The research activity was carried out in San Michele di Ganzaria, a small community (5,000 inhabitants) of Eastern Sicily, $90 \mathrm{~km}$ SouthWest of Catania (Sicily). The site is at an altitude of $490 \mathrm{~m}$ above sea level and is of coordinates $37^{\circ} 170 \mathrm{~N}$ and $14^{\circ} 260 \mathrm{E}$. The climate is Mediterranean. This means that it is mild with temperatures generally not much lower than $0^{\circ} \mathrm{C}$ in winter and not much higher than $36^{\circ} \mathrm{C}$ in summer, despite sometime over $40^{\circ} \mathrm{C}$ were measured in July/August. Rain is not well distributed throughout the year with spring/summer being the driest period (occasional rainfall) and autumn/winter being the wettest. Every year the area receives an average rainfall of $500 \mathrm{~mm}$.

\section{Constructed wetland pilot plant}

The CW pilot plant is located close to the municipal wastewater treatment plant (WWTP) and is made of 2 parallel lines, each one consisting of 6 horizontal sub surface flow (H-SSF) constructed wetland functioning in parallel (Figure 1). In each line, five beds are planted with different macrophyte species, while one bed is unvegetated. In particular Cyperus papirus was planted in H-SSF1 and H-SSF7, Vetiveria zizanoides in H-SSF2 and H-SSF8, Miscanthus $x$ giganteus in H-SSF3 and H-SSF9, Arundo donax in H-SSF4 and H-SSF10, Phragmites australis in H-SSF5 and H-SSF11, while H-SSF6 and H-SSF12 are unplanted. Phragmites, Arundo, Vetivera and Typha are typically used in constructed wetland applications. Miscanthus $x$ giganteus, perennial herbaceous plant suitable for renewable energy source since its high bio-
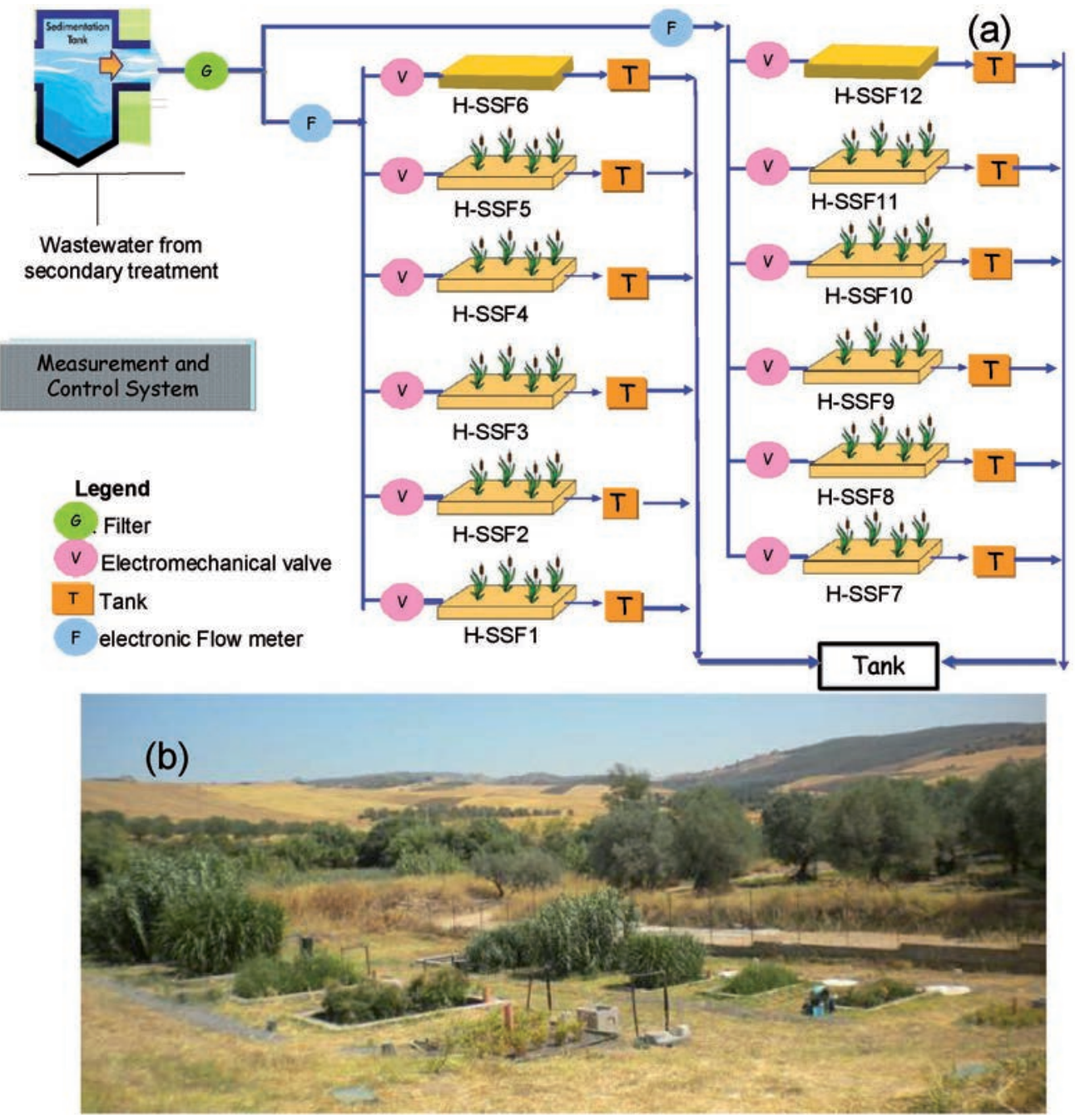

Figure 1. Constructed wetland pilot-scale: schema (a); picture (b). 
mass production (Chou, 2009), is not used in constructed wetland systems. This species was used to compare its removal efficiencies with common wetland-type plants, such as Phragmites, Arundo, Vetivera and Typha. All these emergent herbaceous plants were planted in CWs in November 2011, except Cyperus papyrus that was planted later (January 2012).

Each CW bed is rectangular with a surface area of $4.5 \mathrm{~m}^{2}(1.5 \mathrm{~m} \times$ $3.0 \mathrm{~m}$ ), built of concrete and waterproofed with an impermeable liner. Volcanic gravel $(10-15 \mathrm{~mm})$ was used to fill the bed to an average depth of $0.6 \mathrm{~m}$.

The pilot-scale wetlands were fed in sequence with domestic wastewater treated by WWTP, with a pre-treatment step followed by an Imhoff tank, a trickling filter and secondary settlement. Wastewater from the effluent of the secondary clarifier, first passes through a filter (G), to prevent clogging of wastewater distribution pipes, and then is diverted to the two lines. The influent is distributed at the bed-head through a perforated $5 \mathrm{~mm}$ PEBD pipe transversal to flow direction to allow homogeny wastewater distribution into the bed. Wastewater in the terminal section is intercepted downstream by a transversal perforated pipe connected to an adjustable outlet (spiral plastic pipe) to allow water level control in the filtering bed. Wastewater effluent from each bed, first is collected a in plastic tank (T) (one per bed), where a submersible pump with a water level sensor is located for intermittent emptying of the tank, and then is used for the irrigation of a green area close to the pilot plant. The flow rate treated in the $\mathrm{CW}$ plant (about $65 \mathrm{~L} / \mathrm{h}$ ) was measured by 2 electronic flow meters (F), installed at the inlet pipe of each line and connected to a control panel to record the influent wastewater flow rate. For each bed, a control panel records the influent flow rate, the effluent discharged volume and regulates the open/closing time of the electromechanical valves (V), the latter installed in the inlet pipe of each bed.

A CR510 automatic weather station (Campbell Scientific, Logan, UT) was installed close to the experimental plant to measure air temperature, wind speed and direction, rainfall, global radiation and relative humidity.

\section{Physicochemical and microbiological parameters}

The monitoring campaign was from January 2012 until December 2012 , during which water quality was assessed once per month. Thirteen samples were analyzed per monitoring event, one at the inlet and twelve at the outlet in each reed bed, totalling 126 samples. These samples were analysed according to standard methods (APHA, AWWA, AEF, 2005) for physicochemical parameters such as: total suspended solids (TSS) at $105 \mathrm{C}, \mathrm{COD}$, orthophosphates $\left(\mathrm{PO}_{4}\right)$, Ammonia $\left(\mathrm{NH}_{4}\right)$ and total nitrogen (TN). COD of CW effluent were evaluated on samples filtered by GF/C Whatmann fiber glass.

A total of 64 samples (about 5 from each sampling point) were collected form April 2012 to November 2012. These samples were analysed for microbiological indicators, such as Escherichia coli and Salmonella. The $E$. coli were analysed by standard methods (APHA, AWWA, WEF, 2005) while Salmonella was examined according to the methodology described by Giammanco et al. (2002).

For the physicochemical parameters, the evaluation of treatment performance was based on the removal efficiency percentage, calculated as mean removal percentage of the two beds planted with the same specie. For microbiological parameters, log reductions of cell numbers were calculated.

\section{Water balance and evapotranspiration}

The reference ET $\left(\mathrm{ET}_{0}\right)$ was calculated with a spreadsheet program, PMday.xls (Snyder and Eching, 2009). The program calculates $\mathrm{ET}_{0}$ $\left(\mathrm{mm} \mathrm{d}^{-1}\right)$ using the standardized Penman-Monteith equation (ASCEEWRI, 2004):

$$
E T_{0}=R_{0}+A_{0}
$$

where $R_{0}$ and $A_{0}$ are the radiation and aerodynamic terms of the Penman-Monteith equation for short canopy reference ET with wind speed at $2 \mathrm{~m}$ height $\left(U_{2}, \mathrm{~m} \mathrm{~s}^{-1}\right)$. The influent wastewater flow rate and the effluent wastewater discharged volume, combined with precipitation data measured by a meteorological station located close to plant, were used to estimate the evapotranspiration (ET) rates of the plant species during the vegetative period (from Spring to late Autumn), using a water balance method, as:

$$
E T=\frac{Q_{i}}{A}+P-\frac{D_{v}}{A}
$$

where:

$E T$ (mm day ${ }^{-1}$ ) is the evapotranspiration of the macrophytes, $Q_{i}$ is the influent flow rate $\left(\mathrm{m}^{3}\right.$ day $\left.^{-1}\right), A$ is surface area of H-SSF CW bed $\left(\mathrm{m}^{2}\right)$, $P$ is net precipitation $\left(\mathrm{mm} \mathrm{day}^{-1}\right)$ and $D_{v}$ is the discharged volume $\left(\mathrm{m}^{3}\right.$ day $^{-1}$ ).

ET values were cumulated and averaged over 10-day periods and were used to calculate 10-day plant coefficient $\left(\mathrm{K}_{c}\right)$, according to FAO56 crop coefficient approach (Allen et al., 1998):

$$
K_{c}=\frac{E T}{E T_{0}}
$$

\section{Results and discussion}

\section{Environmental conditions}

The air temperature trend increased from the beginning of April to the beginning of July, followed by an almost constant phase till the end of August and a tendency to decrease up to the end of November. The daily minimum air temperatures ranged from 1.5 to $22.2^{\circ} \mathrm{C}$ and the maximums from 15.0 to $43.4^{\circ} \mathrm{C}$ with an average seasonal value of $20.1^{\circ} \mathrm{C}$ (Table 1$)$.

Total rainfall from April to November was $102.8 \mathrm{~mm}$. During the observation period, the seasonal average wind speed and seasonal total solar radiation were about $0.9 \mathrm{~ms}^{-1}$ and $5253.28 \mathrm{MJ} \mathrm{m}^{-2} \mathrm{~d}^{-1}$ (Table 1).

\section{Water balance and evapotranspiration}

10-day average $\mathrm{ET}_{0}$ and 10-day average $\mathrm{ET}_{\text {con }}$ (ET measured in unplanted CWs) trends were very similar (Figure 2).

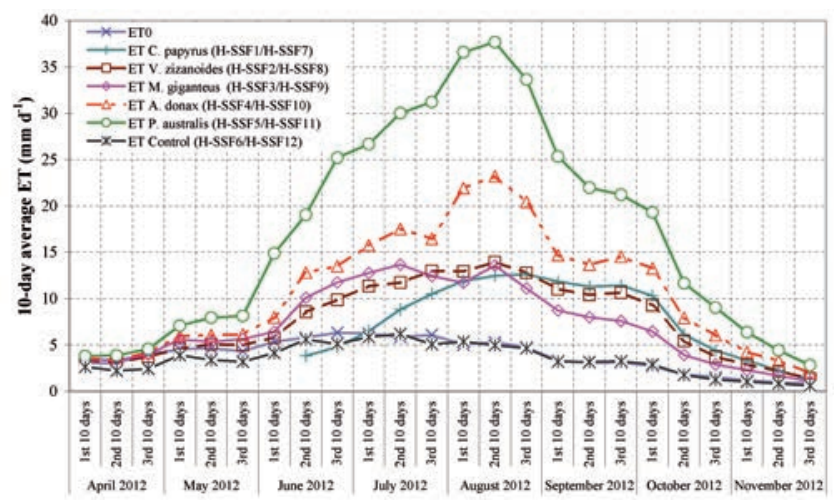

Figure 2. 10-day average ET (from April to December 2012). 
10-day average $\mathrm{ET}_{\text {con }}$ increased from the first 10 days of April $\left(2.2 \mathrm{~mm} \mathrm{~d}^{-1}\right)$ to the second 10 days of June $\left(5.8 \mathrm{~mm} \mathrm{~d}^{-1}\right)$, followed by an almost constant phase till the end of August (average value of $\left.5.3 \mathrm{~mm} \mathrm{~d}^{-1}\right)$ and a tendency to decrease up to the end of the monitored period (minimum value of $0.6 \mathrm{~mm} \mathrm{~d}^{-1}$ in the third decade of October November). From April to November 2012, cumulative $\mathrm{ET}_{\text {con }}$ was $856 \mathrm{~mm}$ (average daily value of $3.5 \mathrm{~mm}$ ) and cumulative $\mathrm{ET}_{0}$ was $961 \mathrm{~mm}$ (average daily value of $3.9 \mathrm{~mm}$ ).

ET measured for plant species were completely different from $\mathrm{ET}_{0}$ and $\mathrm{ET}_{\text {con }}$ underlining the strong effect of vegetation. The 10-day average ET maximum value was detected in the second 10 days of August, with the exception of Cyperus papyrus. Thereafter, 10-day ET declined steadily until the last decade of November. The 10-day average ET trend of C.papyrus, transplanted in the middle of June 2012, was different than those other herbaceous species, transplanted in November 2011. In particular, 10-day average ET of $C$.papyrus increased from the second 10 days of June $\left(3.8 \mathrm{~mm} \mathrm{~d}^{-1}\right)$ to the third 10 days of August $(12.6 \mathrm{~mm}$ $\left.\mathrm{d}^{-1}\right)$, followed by an almost constant phase till the end of September then decreased to 1.2 at the end of November.

The cumulative evapotranspiration (Figure 3) highest value was measured in the CWs vegetated with Phragmites australis $(4,318 \mathrm{~mm})$ followed by Arundo donax (2,706 mm), Vetiveria zizanoides $(1,904$ $\mathrm{mm})$, Myscanthus x giganteus $(1,804 \mathrm{~mm})$ and Cyperus papyrus $(1,421)$. Note that the C.papyrus results was obtained with a 173 day cycle growth whereas the other plant species results were in 244 days.

The average water loss through evapotranspiration process ranged from about 2 (M.giganteus, V.zizanoides, C.papyrus) to 5\% (P.australis) of the influent flow rate, with the highest percentage in August (from 4 to $12 \%)$.

The plant coefficient time patterns of all plant species tested, were similar to the classic trapezium shape of $\mathrm{K}_{\mathrm{c}}$ for agricultural crops (Figure 4). For P.australis and A.donax, 10-day $\mathrm{K}_{\mathrm{c}}$ increased continuously from 1.3 and 1.2 at the start of April to 7.3 and 4.4 at the beginning of August. Thereafter, the values remained almost constant until the first 10 days of October, then decreased to 3.3 (P.australis) and 2.3 (A.donax) at the end of November. The other plant species showed a 10-day $\mathrm{K}_{\mathrm{c}}$ constant phase shorter than a month: from first 10-day of September to first 10-day of October (V.zizanoides and C.papyrus) and from the middle of August to the mid-September (M.giganteus).

\section{Physicochemical and microbiological parameters}

The obtained results show a typical performance of H-SSF constructed wetlands with very high removal of organics and suspended solids comparable with results reported in other studies (Vymazal, 2002; Kadlec and Wallace, 2009). Total Suspended Solids (TSS) removal remained stable in all CW beds despite high variations in influent concentrations, including a spike in concentration recorded in November, greater than $200 \mathrm{mgL}^{-1}$. Except for some samples (about one or two samples per bed), all vegetated beds produced a final TSS effluent concentration of less than $14 \mathrm{mgL}^{-1}$ with a mean removal efficiency up to 88\% ( \pm 15$)$ achieved in Phragmites australis CW (Table 2). An older CW with emergent plants and an extensive root system can enhance TSS removal efficiency by providing a larger surface area, reducing the water velocity and reinforcing settling and filtration in the root network

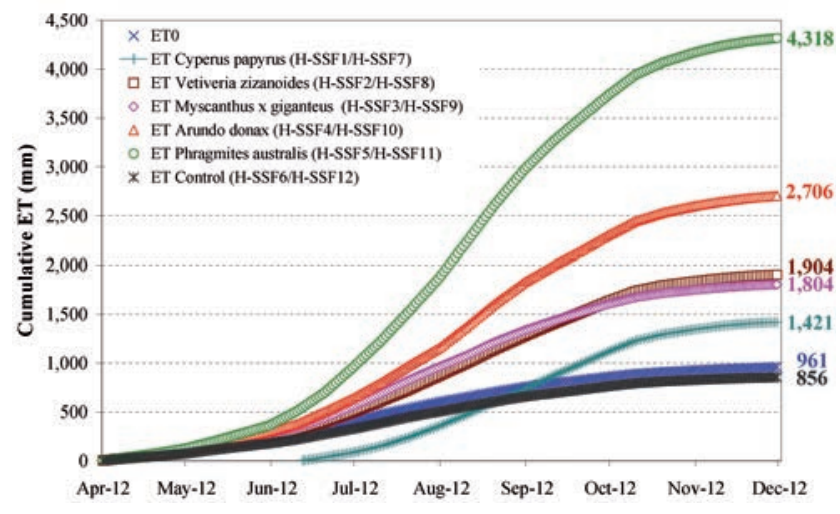

Figure 3. Cumulative ET (from April to December 2012).

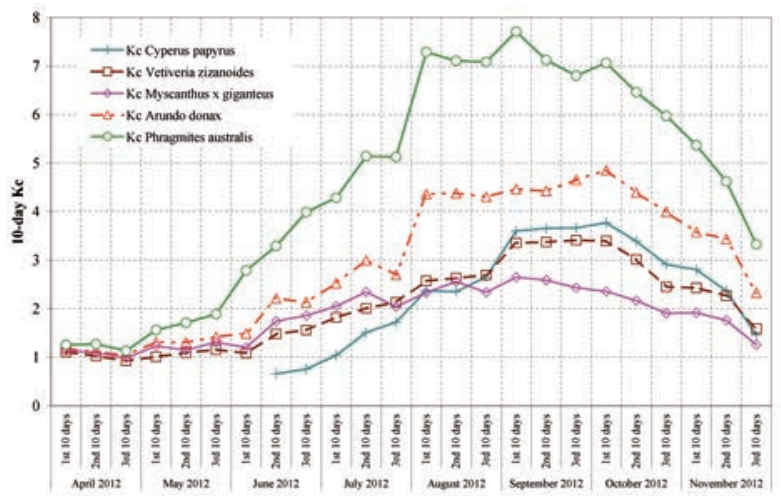

Figure 4. 10-day Kc (from April to December 2012).

Table 1. Monthly meteorological data for the calculation of $\mathbf{E T}_{0}$.

\begin{tabular}{lccccccccccr} 
Variables & Units & Apr & May & Jun & Jul & Aug & Sep & Oct & $\begin{array}{c}\text { Nov } \\
\text { Average } \\
\text { Season }\end{array}$ \\
Cumulative rain & $\mathrm{mm}$ & 66.0 & 5.6 & 0.0 & 4.4 & 0.0 & 8.0 & 18.2 & 0.6 & $102.8^{*}$ \\
Absolute Minimum Air Temp. & ${ }^{\circ} \mathrm{C}$ & 1.5 & 3.9 & 8.2 & 13.4 & 13.9 & 11.7 & 3.3 & 3.4 & 12.5 \\
\hline Absolute Maximum Air Temp. & ${ }^{\circ} \mathrm{C}$ & 27.1 & 29.5 & 37.5 & 43.4 & 42.2 & 35.6 & 34.5 & 25.6 & 28.1 \\
Average Air Temperature & ${ }^{\circ} \mathrm{C}$ & 13.3 & 16.8 & 23.1 & 26.3 & 26.1 & 22.0 & 19.0 & 14.4 & 20.1 \\
\hline Average wind speed & $\mathrm{ms}-1$ & 1.8 & 1.0 & 0.9 & 0.8 & 0.8 & 0.7 & 0.6 & 0.7 & 0.9 \\
Average Relative Humidity & $\%$ & 73.9 & 61.9 & 48.1 & 47.5 & 49.2 & 66.0 & 75.3 & 83.5 & 63.1 \\
\hline Average Solar Radiation & $\mathrm{MJm}^{-2} \mathrm{~d}^{-1}$ & 22.2 & 26.7 & 29.9 & 27.6 & 24.2 & 19.6 & 13.5 & 8.4 & $5253.2^{*}$ \\
\hline
\end{tabular}

*cumulative value 
(Brix 1997, Tanner 2001). Since the wetlands in San Michele di Ganzaria have only been working for 1 year, the observed TSS removal efficiencies could mostly be related to the processes of sedimentation and filtration to the wetland media (Toscano et al., 2013; Stowell et al., 1981).

There was no great difference in the removal performances of organic matter between the vegetated beds, since the mean COD removal was about $60-64 \%$. It has to note that, during the monitor campaign, the Phragmites australis planted bed provided better results than the other planted beds. The average COD effluent concentration was $26( \pm 18)$ $\mathrm{mgL}^{-1}$ in the Cyperus parirus $\mathrm{CW}, 27 \mathrm{mgL}^{-1}( \pm 13)$ in Vetiveria zizanoides, $27( \pm 12)$ in Myscanthus x giganteus, $28( \pm 14)$ in Arundo donax, and the lowest value of $25 \mathrm{mgL}^{-1}( \pm 13)$ was detected in Phragmites australis $\mathrm{CW}$ effluent (Table 2). The COD concentration detected in the effluent of the unvegetated beds (about $36 \mathrm{mgL}^{-1}$ ) was higher than COD concentration recorded in the effluents of planted beds.

Total nitrogen is the sum of all inorganic (ammonium $\mathrm{NH}_{4}$, nitrite $\mathrm{NO}_{2}$ and nitrate $\mathrm{NO}_{3}$ ) and organic forms of nitrogen. Despite plant uptake of nitrogen generally being non-significant for removal of this element in most wetlands receiving treated municipal wastewater (US EPA, 2000), a positive effect of the plants was observed. The average removal efficiencies of $\mathrm{TN}$ and $\mathrm{NH}_{4}$ in the vegetated beds were always higher than that in the unplanted beds. Phragmites australis $\mathrm{CW}$ provided the lowest concentration and the highest removal rate with a mean TN value $9 \mathrm{mgL}^{-1}$ in the effluent and an average reduction efficiency of $64 \%( \pm 12)$.

A slight removal for $\mathrm{PO}_{4}$ (from $24 \%$ to $31 \%$ ) was observed with little differences between the beds (planted or not). This was probably due the very low influent $\mathrm{PO}_{4}$ values (3-5 mgL-1), already close to the "background concentration", and due to the type of substrate used. The major phosphorus removal processes in wetlands are adsorption and precipitation within to soil particles contented $\mathrm{Fe}, \mathrm{Ca}, \mathrm{Al}$ minerals (US EPA, 2000; Faulkner and Richardson, 1989). Gravel material (volcanic material) used in CW pilot plant located in Sam Michele di Ganzaria do not provide a large amounts of phosphorus adsorption due its not low concentrations of $\mathrm{Al}, \mathrm{Fe}$ or $\mathrm{Ca}$, and therefore, the removal effect is low.

$\mathrm{CW}$ systems were highly efficient in reduction of $E$. coli concentrations, in spite of monthly fluctuations observed in the influent (incoming range 5.2-6.0 Ulog). Similar E. coli treatment trends for all planted wetlands were observed with a mean reduction more than 2.5 log units, similar with the results reported in other studies (Kadlec and Wallace,
2009). In particular, E. coli were reduced to a mean value of $2.8 \mathrm{Ulog}$ in the effluent of Cyperus parirus $\mathrm{CW}$ and of Arundo donax, a mean value of 2.9 Ulog $( \pm 0.5)$ in Vetiveria zizanoides and in Myscanthus $x$ giganteus. Maximum E.coli removal (up to $4.3 \mathrm{Ulog}$ ) was achieved in Phragmites australis $\mathrm{CW}$ with a mean concentration value of 2.5 Ulog $( \pm 0.6)$ in the effluent (Table 2). The performance was excellent for Salmonella removal, which was never detected in the effluent of CWs, despite sometime was revealed in the influent.

The slight differences between the performance of the different plant species could be explained by two reasons: probably the plant root system is not yet fully developed since the macrophytes species were planted in November 2011 and the monitoring campaign started in January 2012, and second the nominal residence time (the theoretical time that wastewater should spend in the wetland and during which wastewater can interact with the reactive surfaces) was quite short, about 10-13 hours. The highest evapotranspiration rate highlighted in the P.australis CWs determined longest HRTs, increasing treatment performance.

It could be reductive to evaluate constructed wetland performance just according to removal efficiency. Constructed wetlands, and in general all wastewater treatment plants, are designed to meet at least discharge limits. For this reason, samples expressed as percentages below the wastewater Italian limits for discharge into surface waters (Italian regulation, 2006) and for agriculture reuse (Italian regulation, 2003) have been calculated. In all effluents, COD and TSS concentrations were always below the Italian discharge concentration (35 and 125 $\mathrm{mgL}^{-1}$, respectively). Furthermore, the wetland beds always reduced COD and TN to acceptable concentrations for irrigation (100 and 35 $\mathrm{mgL}^{-1}$ respectively). Despite constructed wetlands have shown a good removal of microbial indicators (up to $4.3 \log$ units in the bed planted with Phragmites australis), they did not produce effluent with $E$. coli levels matching the Italian wastewater reuse standard (50 UFC/100 ml [Maximum value to be detected in $80 \%$ samples for natural treatment systems.]). This result highlights the need for further treatment to achieve the Italian limits required for irrigation reuse.

The tolerable infection risk, associated with the use of wastewaters in "unrestricted irrigation" that includes irrigation of vegetable and salad crops that might be eaten uncooked, was also assessed by applying the microbial risk analyses proposed in the WHO guidelines (2006). Following the WHO reuse guidelines (2006), in 100\% of samples E. coli contamination was less than $10^{4} \mathrm{CFU} 100 \mathrm{~mL}^{-1}$ (Figure 5), correspon-

Table 2. Mean influent $( \pm S D)$ and effluent $( \pm S D)$ wastewater concentrations and mean $( \pm S D)$ pollutant removal efficiencies $(R)$ throughout the monitoring period.

\begin{tabular}{|c|c|c|c|c|c|c|c|c|c|c|c|c|c|}
\hline \multirow[b]{2}{*}{ Influent } & \multirow[t]{2}{*}{$(\mathrm{mg} / \mathrm{L})$} & \multicolumn{2}{|c|}{ SST } & \multicolumn{2}{|c|}{ COD } & \multicolumn{2}{|c|}{$\mathrm{NH}_{4}$} & \multicolumn{2}{|c|}{$\mathrm{N}_{\text {tot }}$} & \multicolumn{2}{|c|}{$\mathrm{PO}_{4}$} & \multicolumn{2}{|c|}{ E. Coli* } \\
\hline & & 102 & (71) & 82 & (36) & 10 & (4) & 25 & (8) & 4 & (1) & 5.6 & $(0.4)$ \\
\hline Cyperus papirus & $\begin{array}{l}\text { out (mg/L) } \\
\text { R (\%) }\end{array}$ & $\begin{array}{c}9 \\
82\end{array}$ & $\begin{array}{l}(4) \\
(24)\end{array}$ & $\begin{array}{l}26 \\
60\end{array}$ & $\begin{array}{l}(18) \\
(30)\end{array}$ & $\begin{array}{c}4 \\
48\end{array}$ & $\begin{array}{l}(2) \\
(38)\end{array}$ & $\begin{array}{c}9 \\
53\end{array}$ & $\begin{array}{l}(3) \\
(21)\end{array}$ & $\begin{array}{c}3 \\
24\end{array}$ & $\begin{array}{l}(1) \\
(20)\end{array}$ & $\begin{array}{l}2.8 \\
2.8\end{array}$ & $\begin{array}{l}(0.2) \\
(0.4)\end{array}$ \\
\hline Vetiveria zizanoides & $\begin{array}{l}\text { out (mg/L) } \\
\text { R (\%) }\end{array}$ & $\begin{array}{l}13 \\
85\end{array}$ & $\begin{array}{l}(19) \\
(16)\end{array}$ & $\begin{array}{l}27 \\
63\end{array}$ & $\begin{array}{l}(13) \\
(19)\end{array}$ & $\begin{array}{c}4 \\
53\end{array}$ & $\begin{array}{l}(2) \\
(18)\end{array}$ & $\begin{array}{l}10 \\
58\end{array}$ & $\begin{array}{l}(4) \\
(13)\end{array}$ & $\begin{array}{c}3 \\
25\end{array}$ & $\begin{array}{l}(1) \\
(19)\end{array}$ & $\begin{array}{l}2.9 \\
2.7\end{array}$ & $\begin{array}{l}(0.5) \\
(0.5)\end{array}$ \\
\hline Myscanthus $\times$ giganteus & $\begin{array}{l}\text { out (mg/L) } \\
\text { R (\%) }\end{array}$ & $\begin{array}{l}13 \\
84\end{array}$ & $\begin{array}{l}(18) \\
(14)\end{array}$ & $\begin{array}{l}27 \\
62 \\
\end{array}$ & $\begin{array}{l}(12) \\
(19)\end{array}$ & $\begin{array}{c}4 \\
52 \\
\end{array}$ & $\begin{array}{l}(2) \\
(23)\end{array}$ & $\begin{array}{l}10 \\
57 \\
\end{array}$ & $\begin{array}{l}(4) \\
(15)\end{array}$ & $\begin{array}{c}3 \\
24 \\
\end{array}$ & $\begin{array}{l}(1) \\
(28)\end{array}$ & $\begin{array}{l}2.9 \\
2.8 \\
\end{array}$ & $\begin{array}{l}(0.6) \\
(0.6)\end{array}$ \\
\hline Arundo donax & $\begin{array}{l}\text { out }(\mathrm{mg} / \mathrm{L}) \\
\mathrm{R}(\%)\end{array}$ & $\begin{array}{l}13 \\
87\end{array}$ & $\begin{array}{l}(20) \\
(13)\end{array}$ & $\begin{array}{l}28 \\
61\end{array}$ & $\begin{array}{l}(14) \\
(23)\end{array}$ & $\begin{array}{c}4 \\
58\end{array}$ & $\begin{array}{l}(1) \\
(22)\end{array}$ & $\begin{array}{l}10 \\
61\end{array}$ & $\begin{array}{l}(5) \\
(15)\end{array}$ & $\begin{array}{c}3 \\
29\end{array}$ & $\begin{array}{l}(1) \\
(24)\end{array}$ & $\begin{array}{l}2.8 \\
2.8\end{array}$ & $\begin{array}{l}(0.4) \\
(0.4)\end{array}$ \\
\hline Phragmites australis & $\begin{array}{l}\text { out (mg/L) } \\
\text { R (\%) }\end{array}$ & $\begin{array}{c}9 \\
88 \\
\end{array}$ & $\begin{array}{l}(14) \\
(15)\end{array}$ & $\begin{array}{l}25 \\
64 \\
\end{array}$ & $\begin{array}{l}\text { (13) } \\
(21)\end{array}$ & $\begin{array}{c}4 \\
61 \\
\end{array}$ & $\begin{array}{l}(2) \\
(21) \\
\end{array}$ & $\begin{array}{c}9 \\
64 \\
\end{array}$ & $\begin{array}{l}(5) \\
(12) \\
\end{array}$ & $\begin{array}{c}3 \\
31 \\
\end{array}$ & $\begin{array}{l}(1) \\
(25) \\
\end{array}$ & $\begin{array}{l}2.5 \\
3.1 \\
\end{array}$ & $\begin{array}{l}(0.6) \\
(0.6) \\
\end{array}$ \\
\hline Unplanted & $\begin{array}{l}\text { out (mg/L) } \\
\text { R (\%) }\end{array}$ & $\begin{array}{l}16 \\
78\end{array}$ & $\begin{array}{l}(21) \\
(18)\end{array}$ & $\begin{array}{l}36 \\
49\end{array}$ & $\begin{array}{l}(17) \\
(27)\end{array}$ & $\begin{array}{c}6 \\
40 \\
\end{array}$ & $\begin{array}{l}(3) \\
(10)\end{array}$ & $\begin{array}{l}14 \\
46\end{array}$ & $\begin{array}{l}(5) \\
(9)\end{array}$ & $\begin{array}{c}3 \\
22\end{array}$ & $\begin{array}{l}(1) \\
(18)\end{array}$ & $\begin{array}{l}3.4 \\
2.2\end{array}$ & $\begin{array}{l}(0.8) \\
(0.7)\end{array}$ \\
\hline
\end{tabular}

*Concentration and removal values in Ulog. 


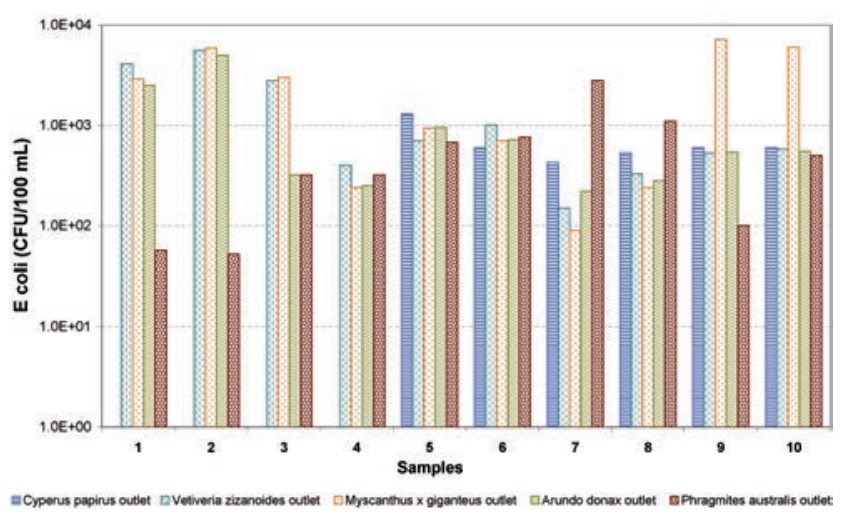

Figure 5. E. Coli concentration trend. ding to a median risk rotavirus infection of $10^{-3}$ pppy, in unrestricted irrigation. So wastewater reclaimed by the constructed wetland system could be used for unrestricted crop irrigation if combined with some post-treatment health protection control measures, such as withholding periods between the last application of a wastewater and harvesting of fruits, in order to obtain the supplementary 2-3 log reduction needed to achieve the health based target of $10^{-6}$ DALY.

\section{Conclusions}

The H-SSF constructed wetland pilot plant, located in San Michele di Ganzaria (Sicily), was highly efficient in the reduction of main chemical, physical and microbiological pollutant concentrations in municipal wastewater. The vegetated beds have showed a better performance in the removal process for all the investigated parameters than unvegetated beds, underlining the active role of macrophytes in the wastewater treatment. The best removal performances obtained in the beds planted with Phragmites australis, confirm that this is the plant specie most suitable to be used in constructed wetlands for wastewater treatment. About the capability to treat wastewater for reuse purposes, $E$. coli concentration in the CW effluents was not always under the maximum limit for wastewater reuse fixed by Italian legislation. This limited impact on Escherichia coli removal means that further treatments are necessary to reuse treated wastewater in agriculture. For example, after CW treatment, stabilization reservoirs could be used to further reduce the microbiological load. On the other hand, the number of $E$. coli in the CW effluents (always less than $10^{4} \mathrm{CFU} 100 \mathrm{~mL}^{-1}$ ) ensures that health-based targets proposed by the WHO guidelines (2006) are easily achievable by combining constructed wetland systems with some post-treatment health protection control measures (such as natural pathogen die-off after the last irrigation).

Finally, during the monitoring period, Phragmites australis showed the highest evapotranspiration rates. For this specie the very high ET rates and Kp values were detected only over a relatively short period (about 30 days, between early and late August), in which the amount of water lost was higher than what is usually considered negligible (about $10 \%$ ) by the most common hydraulic and hydrological models. However, the highest evapotranspiration rate highlighted in the P.australis CWs determined longest HRTs, increasing treatment performance. The small experimental plant may have led to over-estimating macrophytes evapotranspiration, due to the clothesline and oasis effects. However, the results are useful for estimating ET in small subsurface flow (SSF) CWs which serve individual homes. Furthermore, it should be noted that even real scale SSF CWs, which have an area ranging from a few dozen up to several hundred square meters, are affected by advective energy exchanges. So even if the experimental results can not be indiscriminately extrapolated to full-scale systems, they represent a reliable guide for estimating the ET of Phragmites australis, Vetiveria zizanoides, Myscanthus x giganteus, Arundo donax and Cyperus papyrus (Milani and Toscano, 2013; Borin et al., 2011).

\section{References}

Allen R.G., Pereira L.S., Raes D., Smith M. 1998. Crop evapotranspiration: Guidelines for computing crop requirements, FAO Irrigation and Drainage Paper 56. FA0- FAO - Food and Agriculture Organization of the United Nations Press, Rome, Italy.

APHA, AWWA, AEF 2005. Standard methods for the examination of water \& wastewater. $21^{\text {st }}$ edn. Baltimore: American Public Health Association (APHA), AmericanWaterWorks Association (AWWA), and American Environment Federation (AEF). Washington, DC, USA.

ASCE-EWRI. 2004. The ASCE Standardized Reference Evapotranspiration Equation. Technical Committee Report to the Environmental and Water Resources Institute of the American Society of Civil Engineers from the Task Committee on Standardization of Reference Evapotranspiration.

Barbagallo S., Cirelli G.L., Consoli S., Licciardello F., Marzo A., Toscano A. 2012. Analysis of treated wastewater reuse potential for irrigation in Sicily. Water Sci. Technol. 65: 2024-2033.

Borin M., Milani M., Salvato M., Toscano A. 2011. Evaluation of Phragmites australis (Cav.) Trin. evapotranspiration in Northern and Southern Italy. Ecol. Eng. 37: 721-728.

Brix H. 1997. Do macrophytes play a role in constructed wetlands? Water Sci. Technol. 35:11-17.

Chou C.-H. 2009. Miscanthus plants used as an alternative biofuel material: The basic studies on ecology and molecular evolution. Renew. Energ. 34: 1908-1912.

Faulkner S.P., Richardson C.J. 1989. Physical and chemical characteristics of freshwater wetland soils. In: Hammer, D.A. (Ed.), Constructed Wetlands for Wastewater Treatment. Municipal, Industrial and Agricultural. Lewis Publishers, Chelsea, MI, pp. 41-72.

Giammanco G., Pignato S., Alliot M., Polgatti M. 2002. Rapid method for Salmonella enumeration in wastewater. Proc. Iternational Symposium on Salmonella and Salmonellosis. St. Brieuc, France.

Italian regulation, 2003. Italian Technical Guidelines for Wastewater Reuse. D.M. 185/2003. In: Official Journal No. 169, 23/07/2003.

Italian regulation, 2006. Italian Technical Guidelines for Wastewater Dischage in water bodies. D. Lgs 152/2006. In: Official Journal No.88, 03/04/2006.

IWA, 2000. Constructed Wetlands for Pollution Control, Scientific and Technical Report No. 8, IWA Publishing. London, England.

Kadlec R. H., Wallace S. 2009. Treatment Wetlands, $2^{\text {nd }}$ Edition, CRC press, New York, USA.

Katsenovich Y., Hummel-Batista A., Ravinet A. J., Miller J. F. 2009. Performance evaluation of constructed wetlands in a tropical region. Ecol Eng. 35: 1529-1537.

Milani M., Toscano A. 2013. Evapotranspiration from pilot-scale constructed wetlands planted with Phragmites australis in a Mediterranean environment. J. Environ. Sci. Health. A Tox Hazard. Subst. Environ. Eng. 48:568-80.

Snyder R.L., Eching S. 2009. Daily reference evapotranspiration calcu- 
lator user's guide for PMday.xls. University of California, Davis, California.

Stowell R., Tchoba G,. Ludwig R., Colt J. 1981. Concepts in aquatic treatment design. J. Env. Eng. Div. 107: 919-940.

Tanner C. 2001. Plant as ecosystem engineers in subsurface flow treatment wetlands. Water Sci. Technol. 44: 9-17.

Toscano A., Hellio C., Marzo A., Milani M., Lebret K., Cirelli G.L., Langergraber G. 2013. Removal efficiency of a constructed wetland combined with ultrasound and UV devices for wastewater reuse in agriculture. Environ. Technol., (doi 10.1080/09593330.2013. 767284).
US Environmental Protection Agency (EPA), 2000. Constructed Wetlands Treatment of Municipal Wastewaters. Office of Research and Development, Cincinnati, Ohio, USA.

Vymazal J. 2002. The use of sub-surface constructed wetlands for wastewater treatment in the Czech Republic: 10 years experience. Ecol. Eng. 18: 633-646.

Vymazal J. 2009. The use constructed wetlands with horizontal sub-surface flow for various types of wastewater. Ecol. Eng. 35: 1-17.

World Health Organization 2006. Guidelines for the safe use of wastewater, excreta and greywater, Volume 2: Wastewater Use in Agriculture. World Health Organization Press, Geneva, Sweezerland. 